\title{
Effect of Different Weed and Nutrient Management Practices on the Growth and Yield of Kharif Rice in Manipur Valley
}

\author{
Priyanka Irungbam ${ }^{1}$, L. Nabachandra Singh ${ }^{1}$, Edwin Luikham ${ }^{1}$, \\ N. Okendro Singh ${ }^{2}$, Heisnam Punabati ${ }^{3}$ and Y. Bebila Chanu ${ }^{1}$
}

${ }^{1}$ Department of Agronomy, College of Agriculture, Imphal, Manipur, 795004, India

${ }^{2}$ Department of Agricultural Statistics, College of Agriculture, Imphal, Manipur, 795004, India

${ }^{3}$ College of Horticulture and Forestry, Pasighat, Arunachal Pradesh, 791102, India

Central Agricultural University, Imphal, 795004, India

*Corresponding author

\section{Keywords}

Growth, Nutrient Management, Rice, Weed management and yield

Article Info

Accepted:

04 March 2019

Available Online:

10 April 2019

\section{A B S T R A C T}

A field experiment was conducted during the kharif season of 2016 and 2017 in the Research farm of College of Agriculture, Central Agricultural University, Imphal in order to study the effect of different weed and nutrient management practices on the growth and yield of kharif rice. The experiment was laid out in factorial randomized design (FRBD) replicated thrice. The treatments comprised of five levels of weed management practices and three levels of nutrient management practices. The pooled data revealed that among the weed management practices, application of Pyrazosulfuron ethyl (PE) + Hand weeding $(\mathrm{HW})$ at $40 \mathrm{DAS}\left(\mathrm{W}_{2}\right)$ gave the highest plant growth attributes like plant height, number of tillers per $\mathrm{m}^{2}$, leaf area index at all the growth stages of kharif rice and highest grain yield of $48.34 \mathrm{q} \mathrm{ha}^{-1}$ and straw yield of $68.15 \mathrm{q} \mathrm{ha}^{-1}$ but it was significantly at par with Pyrazosulfuron ethyl (PE) + Mechanical weeding (MW) at 40 DAS $\left(\mathrm{W}_{3}\right)$. Among the nutrient management practices, highest grain yield of $43.17 \mathrm{q} \mathrm{ha}^{-1}$ was obtained with the application of 50\% RDF+ 6t FYM $\left(\mathrm{N}_{1}\right)$ followed by the application of 50\% RDF+ Azolla (dual crop)@10t/ha + 3t FYM $\left(\mathrm{N}_{2}\right)$. The interaction between the different weed and nutrient management practices had no significant effect on the growth attributes and yield of kharif rice.

\section{Introduction}

India is one of the world's largest producers of rice, accounting for $20 \%$ of all world rice production which is also the staple food of India. World's rice demand is projected to increase by $25 \%$ from 2001 to 2025 to keep pace with the growing population (IRRI, 2003). A major hindrance in the successful cultivation of direct seeded rice is heavy infestation of weeds which cause drastic reduction in yield. Uncontrolled growth of weeds caused $33-45 \%$ reduction in rice grain yield (Manhas et al., 2012). Heavy losses of 
rice yield occur due to uncontrolled weeds to the extent of complete crop loss under extreme condition by competing for all the resources required for plant growth. With the increase in the cost of labour and their reduced availability, it has become important to search for alternative methods such as herbicide use either alone or in combination with manual or mechanical weeding. The integration of chemical followed by mechanical weeding is cheaper and more effective than hand weeding alone as well as more sustainable than the application of herbicides alone. In rice, weed control by a single method is not remunerative because of higher infestation of weeds. For effective weed management, judicious combination of different weed control practices is essential. Integration of diverse technologies is essential for weed management because weed communities are highly responsive to management practices and environmental conditions (Buhler et al., 2000). Integrated weed management is the long-term, economic and effective management of weed population without excessive reliance on only one method (Yadav et al., 2018).

Complementary use of inorganic and organic sources of plant nutrients is of great importance for maintaining the soil health and productivity of crop. There is an immense need to exploit the alternate source of nutrients viz., organic manures like farmyard manure, vermicompost and biofertilizer to sustain the productivity of rice crop and soil health. Long-term experiments have shown that neither organic sources nor mineral fertilizers alone can achieve sustainability in crop production. Integrated use of organic and mineral fertilizers has been found to be more effective in maintaining higher productivity and stability through correction of deficiencies of secondary and micronutrients in the course of mineralization on one hand and favorable physical and soil ecological conditions on the other (Mallikarjun and Maity, 2017). Injudicious use of agricultural inputs also increases cost of production and energy use, decline in soil fertility and loss of crop and soil biodiversity. Integrated nutrient management (INM) aims at efficient and judicious use of all the sources of plant nutrients in an integrated manner, to attain sustainable crop production with minimum deleterious effect of chemical fertilizers on soil health and least disturbance to the plantsoil-environment.

Thus, integrated weed and nutrient management can play a vital role in the control of weeds in rice cultivation and increasing the soil health and fertility by reducing the dependence on excessive chemical use like herbicides and fertilizers and thus avoid environmental contamination.

\section{Materials and Methods}

The field experiment was conducted at the Research farm of College of Agriculture, Central Agricultural University, Imphal during the kharif season of 2016 and 2017. The soil of the experimental field was clayey in texture. The soil was medium in fertility with good drainage facility with $5.34 \mathrm{pH}$, high in organic carbon with $1.89 \%, 280.88 \mathrm{~kg} \mathrm{ha}^{-1}$ available nitrogen, $32.20 \mathrm{~kg} \mathrm{ha}^{-1}$ available $\mathrm{P}_{2} \mathrm{O}_{5}$ and $270 \mathrm{~kg} \mathrm{ha}$ available $\mathrm{K}_{2} \mathrm{O}$, respectively. The experiment was laid out in a factorial randomized block design (FRBD) in 3 replications. The treatments comprised of 5 levels of weed management practices viz., Pyrazosulfuron ethyl @50g a.i at 7 DAS $\left(\mathrm{W}_{1}\right)$, Pyrazosulfuron ethyl@30g a.i at 7 DAS $+1 \mathrm{HW}$ at 40 DAS $\left(\mathrm{W}_{2}\right)$, Pyrazosulfuron ethyl@30 g a.i at 7 DAS + 1 MW at 40 DAS $\left(\mathrm{W}_{3}\right)$, Pyrazosulfuron ethyl@30g a.i at 7 DAS +2 , 4-D @ 0.75kg a.i at 40 DAS $\left(\mathrm{W}_{4}\right)$ and Control $\left(\mathrm{W}_{5}\right)$ and three levels of nutrient management practices i.e. $50 \% \mathrm{~N}$ from RDF + 6 t FYM $\left(\mathrm{N}_{1}\right), 50 \% \mathrm{~N}$ from RDF + Azolla 
(dual crop)@10 t/ha + 3t FYM $\left(\mathrm{N}_{2}\right)$ and 100\% $\mathrm{RDF}\left(\mathrm{N}_{3}\right)$. The variety used in the experiment was CAU-R1. The plots receiving farmyard manure (FYM) were applied at the time of final puddling operation. The percent nutrient content of the FYM was found to be $0.5 \% \mathrm{~N}$, $0.25 \% \mathrm{P}_{2} \mathrm{O}_{5}$ and $0.5 \% \mathrm{~K}_{2} \mathrm{O}$ respectively. The recommended dose of fertilizer for rice was 60:40:30 kg N, $\mathrm{P}_{2} \mathrm{O}_{5}$ and $\mathrm{K}_{2} \mathrm{O}$ per ha respectively. Half dose of nitrogen $(\mathrm{N})$ and full dose of phosphorus $\left(\mathrm{P}_{2} \mathrm{O}_{5}\right)$ and potassium $\left(\mathrm{K}_{2} \mathrm{O}\right)$ were applied before sowing as basal application in the form of urea, single super phosphate (SSP) and muriate of potash (MOP), respectively. The remaining portion of nitrogen was applied in two splits i.e. half at maximum tillering stage and another half at panicle initiation stage. Sowing of rice was done in the first week of June with a seed rate of $80 \mathrm{~kg} / \mathrm{ha}$ in lines with $20 \mathrm{~cm}$ row to row distance and a plant to plant distance of 10 $\mathrm{cm}$. Azolla was applied in rice as per treatment as a dual crop at 25 DAS @ 10 t/ha. In about 15-20 day time a thick mat of Azolla was formed and was incorporated at 40 DAS. Irrigation was applied as and when required to maintain a shallow depth of submergence (3 to $5 \mathrm{~cm}$ ) beginning with planting and continuing up to 2 weeks before harvesting of the crop. Weed management practices were given as per the treatments. Growth parameters were recorded at 30 days interval and yield was recorded at the time of harvest. The LAI was calculated from area weight relationship using the formula given by Watson (1958)

$$
\mathrm{LAI}=\frac{\text { Area of total number of leaves }}{\text { Ground area from where leaf samples were collected }}
$$

The data so obtained were subjected to statistical analysis by the analysis of variance method described by Panse and Sukhatme (1995) and the significant of different sources of variations were tested by error mean square by Fisher and Snedecor's F test at probability level 0.05 .

\section{Results and Discussion}

\section{Effect of different weed and nutrient management on the growth attributes of rice}

\section{Plant height (cm)}

Different weed and nutrient management practices significantly influenced the plant height of rice in both the seasons at all the growth stages i.e. 30, 60, 90 and 120 DAS respectively. It is evident from Table 1 that plant height kept on increasing from 30 DAS till harvest.

Among the different weed management practices, all the treated plots gave higher plant height as compared to the control plot (Table 1). The pooled date revealed that at 30, 60 DAS and harvest, $\mathrm{W}_{2}$ i.e. application of Pyrazosulfuron ethyl@30 g a.i at 7 DAS + 1 $\mathrm{HW}$ at $40 \mathrm{DAS}$ gave the highest plant height of $46.53 \mathrm{~cm}, 104.07 \mathrm{~cm}$ and $126.84 \mathrm{~cm}$ respectively but it was found to be at par with $\mathrm{W}_{3}$ i.e. application of Pyrazosulfuron ethyl@30 g a.i at 7 DAS + $1 \mathrm{MW}$ at 40 DAS $(46.18 \mathrm{~cm})$ and $\mathrm{W}_{4}$ i.e. application of Pyrazosulfuron ethyl@30 g a.i at 7 DAS + 2,4-D@0.75 kg a.i. at 40 DAS $(45.14 \mathrm{~cm})$ at 30 DAS and $\mathrm{W}_{3}$ at 60 DAS $(102.95 \mathrm{~cm})$ and harvest $(126.38 \mathrm{~cm})$, respectively. At 90 DAS, $W_{4}$ gave the highest plant height of $117.17 \mathrm{~cm}$ but with no significant difference with $\mathrm{W}_{2}(117.12 \mathrm{~cm})$ and $\mathrm{W}_{3}(116.13 \mathrm{~cm})$, respectively. The lowest plant height was observed in the control plot $\mathrm{W}_{5}$ at all the growth stages $(42.17 \mathrm{~cm}, 75.84 \mathrm{~cm}, 102.78$ $\mathrm{cm}$ and $107.41 \mathrm{~cm})$.

Regarding nutrient management treatments, all the treatments were found to have significant effect on the plant height of kharif rice at 30 and 60 DAS but was found to be non significant at 90 DAS and at harvest (Table 1). The pooled data revealed that 
among the three nutrient management practices, $\mathrm{N}_{3}$ i.e. $100 \%$ RDF gave the highest plant height at all the growth stages i.e., 30, 60, 90 DAS and at harvest with a plant height of $46.15 \mathrm{~cm}, 100.19 \mathrm{~cm}, 115.45 \mathrm{~cm}$ and $121.52 \mathrm{~cm}$ respectively. However, $\mathrm{N}_{1}$ i.e. application of $50 \%$ RDF $+6 \mathrm{t}$ FYM was found to be at par with $\mathrm{N}_{3}$ at 30 DAS with a height of $45.48 \mathrm{~cm}$. Significantly lowest plant height was observed with $50 \% \mathrm{~N}$ from RDF + Azolla (dual crop) @ 10 t/ha + 3 t FYM $\left(\mathrm{N}_{2}\right)$ at $30(42.74 \mathrm{~cm})$ and 60 DAS $(90.61 \mathrm{~cm})$ respectively. This might be attributed due to the fact that higher doses of nutrients resulted in higher availability of nutrients in the soil for plant nourishment and further, organic source which slow release and continuous availability of nutrients enhanced cell division, elongation as well as various metabolic processes which ultimately increased the plant height. The results were in close conformity with the findings of Krishna et al., (2008), Dutt and Chauhan (2010) and Murthy (2012). Integration of 25 or $50 \%$ organic nutrients such as FYM with 50 or $75 \%$ inorganic fertilizer release nutrients slowly and continuously to the plant and improved soil environment for better root penetration leading to better absorption of moisture and nutrients and produced better plant height and growth. Application of FYM also lead to reduced loss of $\mathrm{N}$ by fixation of $\mathrm{NH}^{+4}$ ion with humus present in FYM and increased availability of $\mathrm{N}$ to crop which ultimately increased the plant height. This was also similar to the results obtained by Singh et al., 2018. The interaction effect between the different weed and nutrient management practices on plant height of kharif rice was found to be non significant at all the growth stages.

\section{Number of tillers $\mathbf{m}^{-1}$}

Integrated weed and nutrient management practices had significant effect on the number of tillers per $\mathrm{m}^{2}$ in both the seasons of kharif 2016 and 2017. The results (Table 2) revealed that the number of tillers per $\mathrm{m}^{2}$ increased from 30 DAS to 90 DAS and thereafter followed a decreasing trend till 120 DAS.

Among the different weed management practices, the plot receiving PE@ 30g a.i at 7 $\mathrm{DAS}+1 \mathrm{HW}$ at 40 DAS i.e., $\mathrm{W}_{2}$ gave the highest number of tillers per $\mathrm{m}^{2}$ at 30 DAS which was followed by the plot receiving PE@30 g a.i at 7 DAS + $1 \mathrm{MW}$ at $40 \mathrm{DAS}$ i.e., $\mathrm{W}_{3}(442.50)$ and $\mathrm{W}_{4}$ i.e. PE@30g a.i at 7 DAS + 2, 4-D @ 0.75kg a.i at 40 DAS (430.83) but they were at par with each other. Similarly at 60, 90 and 120 DAS also, $W_{2}$ gave the highest number of tillers per $\mathrm{m}^{2}$ (983.22, 551.47 and 530.26 respectively) which was followed by $\mathrm{W}_{3}(941.17,533.81$ and 502.29 respectively) but were at par with each other. The lowest number of tillers per $\mathrm{m}^{2}$ was observed in the control plot $\mathrm{W}_{5}$ at all the growth stages i.e. 30, 60, 90 and 120 DAS with a value of 199.53, 377.36, 269.19 and 270.07 respectively. Similar trend of variation was observed in both the seasons of study i.e., kharif season of 2016 and 2017, respectively. According to Rawat et al., (2012), crop under weed free plots attained lush growth due to elimination of weeds from inter and intra row spaces besides better aeration due to manipulation of surface soil and thus more spaces, water, light and nutrients were available for the better growth and development, which resulted in to superior growth and yield and consequently the highest yield of crop.

Among the different nutrient management practices, $\mathrm{N}_{3}$ i.e. $100 \%$ RDF gave the highest number of tillers per $\mathrm{m}^{2}$ at 30, 60 and 90 DAS with a value of $403.72,851.65$ and 479.42 respectively but it was found to be at par with the treatment receiving $50 \% \mathrm{~N}$ from RDF +6 t FYM i.e. $\mathrm{N}_{1}$ (397.00, 815.37 and 474.00). At 120 DAS, $\mathrm{N}_{1}$ gave the highest number of 
tillers per $\mathrm{m}^{2}$ (467.27) but was significantly at par with $\mathrm{N}_{3}$ (451.98). The treatment receiving $50 \% \mathrm{~N}$ from RDF + Azolla (dual crop) @ 10 $\mathrm{t} / \mathrm{ha}+3 \mathrm{t} \mathrm{FYM}\left(\mathrm{N}_{2}\right)$ gave the lowest number of tillers per $\mathrm{m}^{2}$ at all the growth stages of rice (Table 2). The same trend was also observed in both the seasons of kharif rice. The increase in crop growth attributes may be contributed to the mineralization of FYM or through solubilization of nutrients from native source during the process of decomposition. Better crop growth with combined use of nutrients in desired quantity may be attributed to improvement in physicochemical and biological properties of soil by maintaining continuous supply of nutrient to the crop.

\section{Leaf area index}

At 30 DAS, the highest LAI was observed in $\mathrm{W}_{3}$ and $\mathrm{W}_{4}$ i.e. PE@30 g a.i at 7 DAS + 1 MW at 40 DAS and PE@30g a.i at 7 DAS + 2, 4-D@0.75kg a.i at 40 DAS with a value of 1.37 each which was followed by $\mathrm{W}_{2}$ i.e., PE@30g a.i at $7 \mathrm{DAS}+1 \mathrm{HW}$ at $40 \mathrm{DAS}$ with a value of 1.33 (Table 3 ). However, all the above three treatments were found to be at par with each other.

At 60 DAS, $W_{2}$ gave the highest LAI (6.07) followed by $\mathrm{W}_{3}$ (5.84) but there was no significant difference between them. At 90 and $120 \mathrm{DAS}_{3} \mathrm{~W}_{3}$ gave the highest LAI (8.67, 7.54) followed by $\mathrm{W}_{2}(8.45$ and 7.19) but with no significant difference between them. $\mathrm{W}_{1}$ gave lower LAI values as compared to the other treatments except for control. $\mathrm{W}_{5}$ i.e. the control plot gave the lowest LAI in all the stages $(0.87, \quad 1.67,3.83$ and 3.15 , respectively). Shendage et al., 2017 also observed that combination of chemical and cultural/physical control measures proved better for obtaining higher growth and yield with from rice than the application of chemical herbicides, cultural and mechanical control alone. Significantly superior crop growth attributes recorded by the treatment receiving herbicide along with hand weeding or mechanical weeding may be due to higher weed control efficiency associated with the treatments which may have resulted in lower crop-weed competition effecting better crop growth and development.

Among the nutrient management practices, the plot receiving $100 \% \mathrm{RDF}\left(\mathrm{N}_{3}\right)$ gave the highest LAI at all the growth stages (1.34, $5.18,7.68$ and 6.68 , respectively). It was followed by the plot receiving $50 \% \mathrm{~N}$ from RDF+ 6 t FYM i.e. $\mathrm{N}_{1}(1.23,4.95,7.49$ and $6.33)$ but there was no significant difference between them at 30 and 90 DAS. $\mathrm{N}_{2}$ gave the lowest LAI at all the growth stages of rice among the three nutrient management practices (Table 3).

\section{Effect of different weed and nutrient management on the yield of rice}

\section{Grain yield (q ha-1)}

The pooled data revealed that among the different weed management practices, highest grain yield (48.34 $\mathrm{q} \mathrm{ha}^{-1}$ ) was recorded with the application of PE@30g a.i at 7 DAS + 1 $\mathrm{HW}$ at 40 DAS $\left(\mathrm{W}_{2}\right)$ which was comparable with the treatment $\mathrm{W}_{3}$ i.e. PE@30 g a.i at 7 DAS + $1 \mathrm{MW}$ at $40 \mathrm{DAS}\left(46.70 \mathrm{q} \mathrm{ha}^{-1}\right)$ but significantly higher than the plot with PE@30g a.i at 7 DAS + 2, 4-D @0.75kg a.i at 40 DAS i.e. $\mathrm{W}_{4}\left(44.43 \mathrm{q} \mathrm{ha}^{-1}\right)$ and PE @ 50g a.i at 7 DAS i.e. $\mathrm{W}_{1}\left(41.75 \mathrm{q} \mathrm{ha}^{-1}\right)$.

The lowest grain yield was obtained from the weedy check plot, $\mathrm{W}_{5}\left(27.47 \mathrm{q} \mathrm{ha}^{-1}\right)$ which was significantly lower than any other treatments (Table 4). The higher grain yield obtained with the above treatments is due to better control of weeds and thus reduced competition and minimum nutrient removal by weeds which might have increased the capacity of nutrient uptake and enhanced the 
source and sink sizes which led to increase in the yield attributes viz., panicle number per hill, panicle length and number of filled grains per panicle. Similar finding was also observed by Parameswari and Srinivas, 2014.

It is evident from the pooled data in Table 4 that the highest grain yield of rice $(43.17 \mathrm{q} \mathrm{ha}$ ${ }^{1}$ ) was recorded with the application of $50 \% \mathrm{~N}$ from RDF + 6t FYM $\left(\mathrm{N}_{1}\right)$ which was at par with $\mathrm{N}_{2}$ i.e. the application of $50 \% \mathrm{~N}$ from RDF + Azolla (dual crop)@ 10 t/ha + 3t FYM $\left(41.92 \mathrm{q} \mathrm{ha}^{-1}\right)$ but significantly higher than the application of $100 \% \operatorname{RDF}\left(\mathrm{N}_{3}\right)$ with a value of
$40.12 \mathrm{q} \mathrm{ha}^{-1}$. In the first year i.e. 2016, $\mathrm{N}_{2}$ recorded significantly lowest grain yield $\left(39.20 \mathrm{q} \mathrm{ha}^{-1}\right)$ but increase in grain yield was observed in the second year where $\mathrm{N}_{2}$ recorded $44.65 \mathrm{q} \mathrm{ha}^{-1}$ which was statistically comparable with $\mathrm{N}_{1}\left(44.40 \mathrm{q} \mathrm{ha}^{-1}\right)$ and significantly higher than $\mathrm{N}_{3}\left(39.18 \mathrm{q} \mathrm{ha}^{-1}\right)$ Shanmugan and Veeraputhran (2001).

Bhattacharya et al., (2003) also reported beneficial effects of FYM on yield of rice due to better nutrition of crop. Similar finding was also observed by Latha et al., 2019.

Table.1 Effect of integrated weed and nutrient management on plant height $(\mathrm{cm})$ of kharif rice

\begin{tabular}{|c|c|c|c|c|c|c|c|c|c|c|c|c|}
\hline \multirow[t]{2}{*}{ Treatment } & \multicolumn{3}{|c|}{30 DAS } & \multicolumn{3}{|c|}{60 DAS } & \multicolumn{3}{|c|}{90 DAS } & \multicolumn{3}{|c|}{$120 \mathrm{DAS}$} \\
\hline & 2016 & 2017 & Pooled & 2016 & 2017 & Pooled & 2016 & 2017 & Pooled & 2016 & 2017 & Pooled \\
\hline W1 & 39.27 & 48.56 & 43.92 & 98.39 & 95.31 & 96.85 & 117.14 & 115.55 & 116.34 & 121.36 & 117.11 & 119.24 \\
\hline W2 & 41.33 & 51.73 & 46.53 & 106.19 & 101.95 & 104.07 & 119.45 & 114.78 & 117.12 & 129.19 & 124.48 & 126.84 \\
\hline W3 & 40.34 & 52.02 & 46.18 & 04.74 & 101.17 & 102.95 & 118.98 & 113.28 & 116.13 & 128.58 & 124.19 & 126.38 \\
\hline W4 & .03 & 50.26 & 45.14 & 1.46 & 98.04 & 99.75 & 9.45 & 114.88 & 117.17 & 122.44 & 122.54 & 122.49 \\
\hline W5 & 38.39 & 45.96 & 42.17 & 74.63 & 77.04 & 75.84 & 109.32 & 96.24 & 102.78 & 111.19 & 103.63 & 107.41 \\
\hline $\operatorname{SEm}( \pm)$ & 0.749 & 0.84 & 0.60 & 1.65 & 1.05 & 0.95 & 1.08 & 1.58 & 1.04 & 1.54 & 1.32 & 0.99 \\
\hline $\mathrm{CD}(\mathrm{p}=0.05)$ & NS & 2.44 & 1.74 & 4.79 & 3.04 & 2.76 & 3.12 & 4.56 & 3.03 & 4.47 & 3.81 & 2.87 \\
\hline $\mathrm{N} 1$ & 40.97 & 49.98 & 45.48 & 97.63 & 96.12 & 96.87 & 116.58 & 109.58 & 113.08 & 121.75 & 119.45 & 120.60 \\
\hline $\mathrm{N} 2$ & 38.20 & 47.29 & 42.74 & 90.73 & 90.51 & 90.61 & 116.35 & 110.03 & 113.19 & 120.45 & 118.16 & 119.30 \\
\hline N3 & 40.45 & 51.85 & 46.15 & 102.91 & 97.48 & 100.19 & 117.68 & 113.23 & 115.45 & 125.47 & 117.57 & 121.52 \\
\hline SEm( & 0.580 & 0.65 & 0.46 & 1.28 & 0.81 & 0.74 & 0.83 & 1.22 & 0.81 & 1.20 & 1.02 & 0.77 \\
\hline $\mathrm{CD}(\mathrm{p}=0.05)$ & 1.680 & 1.89 & 1.34 & 3.71 & 2.36 & 2.14 & NS & NS & NS & 3.46 & NS & NS \\
\hline
\end{tabular}

$\mathrm{W}_{1}:$ PE @50g a.i at $7 \mathrm{DAS}$

$\mathrm{W}_{2}:$ PE@30g a.i at $7 \mathrm{DAS}+1 \mathrm{HW}$ at $40 \mathrm{DAS}$

$\mathrm{W}_{3}$ : PE@30 g a.i at $7 \mathrm{DAS}+1 \mathrm{MW}$ at $40 \mathrm{DAS}$

W: PE@30g a.i at 7 DAS + 2, 4-D @ 0.75kg a.i at 40 DAS

$\mathrm{W}_{5}$ : Control

$\mathrm{N}_{1}: 50 \% \mathrm{~N}$ from RDF + $6 \mathrm{t}$ FYM

$\mathrm{N}_{2}: 50 \% \mathrm{~N}$ from RDF + Azolla (dual crop) @ 10 t/ha + 3t FYM

$\mathrm{N}_{3}: 100 \% \mathrm{RDF}$

DAS: Days after sowing, PE: Pyrazosulfuron ethyl, HW: Hand weeding, MW: Mechanical weeding

FYM: Farmyard manure 
Int.J.Curr.Microbiol.App.Sci (2019) 8(4): 128-137

Table.2 Effect of integrated weed and nutrient management on number of tillers per $\mathrm{m} 2$ of kharif rice

\begin{tabular}{|c|c|c|c|c|c|c|c|c|c|c|c|c|}
\hline \multirow{2}{*}{ Treatment } & \multicolumn{3}{|c|}{30 DAS } & \multicolumn{3}{c|}{60 DAS } & \multicolumn{3}{c|}{90 DAS } & \multicolumn{3}{c|}{120 DAS } \\
\cline { 2 - 15 } & 2016 & 2017 & Pooled & 2016 & 2017 & Pooled & 2016 & 2017 & Pooled & 2016 & 2017 & Pooled \\
\hline W1 & 378.33 & 356.11 & 367.22 & 885.56 & 815.17 & 850.36 & 503.23 & 431.94 & 467.59 & 473.54 & 456.67 & 465.10 \\
\hline W2 & 455.00 & 456.67 & 455.83 & 1025.22 & 941.22 & 983.22 & 552.78 & 550.17 & 551.47 & 542.19 & 518.33 & 530.26 \\
\hline W3 & 442.22 & 442.78 & 442.50 & 939.44 & 942.89 & 941.17 & 542.61 & 525.00 & 533.81 & 502.80 & 501.78 & 502.29 \\
\hline W4 & 447.78 & 413.89 & 430.83 & 924.72 & 889.17 & 906.94 & 513.37 & 462.06 & 487.71 & 487.22 & 475.22 & 481.22 \\
\hline W5 & 210.56 & 188.50 & 199.53 & 455.56 & 299.17 & 377.36 & 300.00 & 238.39 & 269.19 & 279.09 & 261.06 & 270.07 \\
\hline SEm( \pm$)$ & 19.55 & 16.96 & 11.59 & 22.02 & 14.44 & 13.90 & 15.55 & 12.88 & 9.20 & 17.37 & 13.42 & 11.48 \\
\hline CD(p=0.05) & 56.64 & 49.12 & 33.57 & 63.79 & 41.84 & 40.25 & 45.04 & 37.30 & 26.66 & 50.33 & 38.86 & 33.27 \\
\hline N1 & 385.67 & 408.33 & 397.00 & 844.57 & 786.17 & 815.37 & 474.67 & 473.33 & 474.00 & 465.73 & 468.80 & 467.27 \\
\hline N2 & 341.33 & 332.33 & 336.83 & 796.50 & 740.33 & 768.42 & 439.36 & 425.53 & 432.45 & 426.77 & 433.47 & 430.12 \\
\hline N3 & 433.33 & 374.10 & 403.72 & 897.23 & 806.07 & 851.65 & 533.17 & 425.67 & 479.42 & 478.40 & 425.57 & 451.98 \\
\hline SEm( \pm$)$ & 15.15 & 13.13 & 8.98 & 17.06 & 11.19 & 10.76 & 12.04 & 9.97 & 7.13 & 13.46 & 10.39 & 8.90 \\
\hline CD(p=0.05) & 43.87 & 38.05 & 26.00 & 49.42 & 32.41 & 31.18 & 34.89 & 28.89 & 20.65 & 38.98 & 30.10 & 25.77 \\
\hline
\end{tabular}

Table.3 Effect of integrated weed and nutrient management on leaf area index (LAI) of kharif rice

\begin{tabular}{|c|c|c|c|c|c|c|c|c|c|c|c|c|}
\hline \multirow[t]{2}{*}{ Treatment } & \multicolumn{3}{|c|}{$30 \mathrm{DAS}$} & \multicolumn{3}{|c|}{60 DAS } & \multicolumn{3}{|c|}{90 DAS } & \multicolumn{3}{|c|}{$120 \mathrm{DAS}$} \\
\hline & 2016 & 2017 & Pooled & 2016 & 2017 & Pooled & 2016 & 2017 & Pooled & 2016 & 2017 & Pooled \\
\hline W1 & 1.23 & 1.20 & 1.22 & 5.46 & 5.06 & 5.26 & 7.83 & 8.03 & 7.93 & 6.56 & 7.08 & 6.82 \\
\hline W2 & 1.28 & 1.38 & 1.33 & 6.31 & 5.83 & 6.07 & 8.40 & 8.49 & 8.45 & 7.26 & 7.13 & 7.19 \\
\hline W3 & 1.31 & 1.44 & 1.37 & 5.72 & 5.96 & 5.84 & 8.66 & 8.68 & 8.67 & 7.73 & 7.36 & 7.54 \\
\hline W4 & 1.29 & 1.44 & 1.37 & 5.50 & 5.14 & 5.32 & 7.95 & 8.06 & 8.00 & 6.85 & 6.91 & 6.88 \\
\hline W5 & 0.81 & 0.93 & 0.87 & 1.80 & 1.54 & 1.67 & 3.69 & 3.97 & 3.83 & 3.27 & 3.04 & 3.15 \\
\hline $\operatorname{SEm}( \pm)$ & 0.07 & 0.07 & 0.05 & 0.13 & 0.16 & 0.09 & 0.16 & 0.18 & 0.11 & 0.12 & 0.10 & 0.08 \\
\hline $\mathrm{CD}(\mathrm{p}=0.05)$ & 0.20 & 0.19 & 0.14 & 0.36 & 0.46 & 0.27 & 0.47 & 0.53 & 0.33 & 0.36 & 0.28 & 0.24 \\
\hline N1 & 1.18 & 1.28 & 1.23 & 4.99 & 4.91 & 4.95 & 7.53 & 7.46 & 7.49 & 6.44 & 6.22 & 6.33 \\
\hline N2 & 1.12 & 1.12 & 1.12 & 4.49 & 4.25 & 4.37 & 6.83 & 7.08 & 6.96 & 5.87 & 6.03 & 5.95 \\
\hline N3 & 1.25 & 1.43 & 1.34 & 5.40 & 4.96 & 5.18 & 7.56 & 7.80 & 7.68 & 6.70 & 6.66 & 6.68 \\
\hline $\operatorname{SEm}( \pm)$ & 0.05 & 0.05 & 0.04 & 0.10 & 0.12 & 0.07 & 0.13 & 0.14 & 0.09 & 0.10 & 0.08 & 0.06 \\
\hline $\mathrm{CD}(\mathrm{p}=0.05)$ & NS & 0.15 & 0.11 & 0.28 & 0.36 & 0.21 & 0.37 & 0.41 & 0.26 & 0.28 & 0.22 & 0.18 \\
\hline
\end{tabular}


Table.4 Effect of integrated weed and nutrient management on yield of kharif rice

\begin{tabular}{|c|c|c|c|c|c|c|c|c|c|}
\hline \multirow{2}{*}{ Treatment } & \multicolumn{3}{|c|}{ Grain yield (q/ha) } & \multicolumn{3}{c|}{ Straw yield (q/ha) } & \multicolumn{3}{c|}{ Harvest index (\%) } \\
\cline { 2 - 12 } & 2016 & 2017 & Pooled & 2016 & 2017 & Pooled & 2016 & 2017 & Pooled \\
\hline $\mathrm{W} 1$ & 39.95 & 43.54 & 41.75 & 52.97 & 59.98 & 56.47 & 42.97 & 41.99 & 42.48 \\
\hline $\mathrm{W} 2$ & 47.78 & 48.90 & 48.34 & 64.78 & 71.51 & 68.15 & 42.42 & 40.69 & 41.56 \\
\hline $\mathrm{W} 3$ & 43.39 & 50.00 & 46.70 & 57.32 & 68.79 & 63.06 & 43.09 & 42.13 & 42.61 \\
\hline $\mathrm{W} 4$ & 42.65 & 46.21 & 44.43 & 56.52 & 63.78 & 60.15 & 43.00 & 42.02 & 42.51 \\
\hline $\mathrm{W} 5$ & 29.87 & 25.07 & 27.47 & 41.37 & 34.08 & 37.73 & 41.96 & 42.65 & 42.30 \\
\hline $\mathrm{SEm}( \pm)$ & 0.94 & 1.33 & 0.89 & 1.17 & 2.47 & 1.50 & 0.30 & 0.73 & 0.40 \\
\hline $\mathrm{CD}(\mathrm{p}=0.05)$ & 2.72 & 3.86 & 2.59 & 3.39 & 7.16 & 4.35 & $\mathrm{NS}$ & $\mathrm{NS}$ & $\mathrm{NS}$ \\
\hline $\mathrm{N} 1$ & 41.94 & 44.40 & 43.17 & 55.96 & 60.69 & 58.32 & 42.73 & 42.77 & 42.75 \\
\hline $\mathrm{N} 2$ & 39.20 & 44.65 & 41.92 & 52.95 & 60.46 & 56.70 & 42.55 & 42.45 & 42.50 \\
\hline $\mathrm{N} 3$ & 41.05 & 39.18 & 40.12 & 54.88 & 57.74 & 56.31 & 42.79 & 40.47 & 41.63 \\
\hline $\mathrm{SEm}( \pm)$ & 0.73 & 1.03 & 0.69 & 0.91 & 1.91 & 1.16 & 0.24 & 0.57 & 0.31 \\
\hline $\mathrm{CD}(\mathrm{p}=0.05)$ & 2.10 & 2.99 & 2.01 & $\mathrm{NS}$ & $\mathrm{NS}$ & $\mathrm{NS}$ & $\mathrm{NS}$ & 1.65 & 0.90 \\
\hline
\end{tabular}

$\mathrm{W}_{1}:$ PE @ $50 \mathrm{~g}$ a.i at $7 \mathrm{DAS}$

$\mathrm{W}_{2}$ : PE@30g a.i at $7 \mathrm{DAS}+1 \mathrm{HW}$ at $40 \mathrm{DAS}$

$\mathrm{W}_{3}$ : PE@30 g a.i at $7 \mathrm{DAS}+1 \mathrm{MW}$ at $40 \mathrm{DAS}$

$\mathrm{W}_{4}$ : PE@30g a.i at 7 DAS + 2, 4-D @ 0.75kg a.i at 40 DAS

$\mathrm{W}_{5}$ : Control

$\mathrm{N}_{1}: 50 \% \mathrm{~N}$ from RDF + $6 \mathrm{t}$ FYM

$\mathrm{N}_{2}: 50 \% \mathrm{~N}$ from RDF + Azolla (dual crop)@10 t/ha + 3t FYM

$\mathrm{N}_{3}: 100 \% \mathrm{RDF}$

DAS: Days after sowing, PE: Pyrazosulfuron ethyl, HW: Hand weeding, MW: Mechanical weeding

FYM: Farmyard manure

\section{Straw yield $\left(\mathrm{q} \mathrm{ha}^{-1}\right)$}

The data in the table revealed a significant increase in straw yield by employing different weed management practices (Table 4). The pooled data showed that application of PE@30g a.i at 7 DAS + $1 \mathrm{HW}$ at 40 DAS $\left(\mathrm{W}_{2}\right)$ gave the maximum straw yield of 68.15 $\mathrm{q} \mathrm{ha}{ }^{-1}$ followed by the application of PE@30 $\mathrm{g}$ a.i at $7 \mathrm{DAS}+1 \mathrm{MW}$ at 40 DAS i.e. $\mathrm{W}_{3}$ $\left(63.06 \mathrm{q} \mathrm{ha}^{-1}\right)$ and PE@30g a.i at $7 \mathrm{DAS}+2$, 4-D @ 0.75kg a.i at 40 DAS i.e. $\mathrm{W}_{4}(60.15 \mathrm{q}$ $\mathrm{ha}^{-1}$ ) but $\mathrm{W}_{3}$ and $\mathrm{W}_{4}$ was statistically at par with each other. Less competition for nutrients between the crop and weeds led to taller plants, more number of tillers and dry matter production which in turn resulted in higher straw yield. Similar result was also reported by Subramanyam et al., 2007. The lowest straw yield was observed in weedy check, $\mathrm{W}_{5}\left(37.73 \mathrm{q} \mathrm{ha}^{-1}\right)$ followed by the application of PE @ 50g a.i at 7 DAS i.e. $W_{1}$ $\left(56.47 \mathrm{q} \mathrm{ha}^{-1}\right)$. Lowest grain and straw yield was obtained in control plot due to severe weed competition exerted by grasses, sedges and broad leaved weeds for space, light, moisture and nutrients throughout the growth period. Similar results were reported by Hussain et al., (2008) and Shendage et al., (2017).

The different nutrient management practices had no significant difference on the straw yield of rice as evident from the data in the table. However, higher straw yield (58.32 q $\mathrm{ha}^{-1}$ ) was recorded with the application of 
$50 \% \mathrm{~N}$ from RDF + 6t FYM $\left(\mathrm{N}_{1}\right)$ followed by $\mathrm{N}_{2}\left(56.70 \mathrm{q} \mathrm{ha}^{-1}\right)$ i.e. application of $50 \% \mathrm{~N}$ from RDF + Azolla (dual crop)@10 t/ha + 3t FYM and the lowest was observed in $100 \%$ $\operatorname{RDF}\left(\mathrm{N}_{2}\right)$ with $56.31 \mathrm{q} \mathrm{ha}^{-1}$.

\section{Harvest index (\%)}

Harvest index of rice was not significantly affected by the application of different weed management practices during both the years of experimentation as well as in the pooled data as is evident from Table 4. However, higher harvest index $(42.61 \%)$ was observed in the treatment receiving PE@30 g a.i at 7 $\mathrm{DAS}+1 \mathrm{MW}$ at $40 \mathrm{DAS}\left(\mathrm{W}_{3}\right)$ among the different weed management practices.

Among the different nutrient management practices, $\mathrm{N}_{1}$ i.e. $50 \% \mathrm{~N}$ from $\mathrm{RDF}+6 \mathrm{t} \mathrm{FYM}$ recorded the maximum harvest index of 42.75 $\%$ but with no significant difference with the treatment of $50 \% \mathrm{~N}$ from RDF + Azolla (dual crop)@10 t/ha + 3t FYM (42.50\%). The lowest was observed in the plot receiving $100 \%$ RDF with $41.63 \%$. Combination of different organic sources and inorganic fertilizers is an efficient exogenous source of plant nutrients. Balanced use of fertilizers along with complementary use of organic and bio sources can help reverse environmental degradation by providing much needed nutrients to the soil, thereby increasing crop yield (Sudhanshu, 2013). No significant interaction between the different weed and nutrient management practices was observed with regard to grain yield, straw yield and harvest index in either of the years as well as in the pooled data.

\section{References}

Bhattacharya, S.P., Sitangshu, S., Karimadkar, A.J., Bera, P.S., Lalitha, M., Sarkar, S and Mandal, L. 2003. Effects of humic acid on the growth and yield of transplanted summer rice. Environment and ecology, 21(3): 680683.

Buhler, D.D., Liebman, M. and Obrycki, J.J. (2000). Theoretical and practical challenges to an IPM approach to weed management. Weed Sci. 48: 274-280.

Dutta, M. and Chauhan, B.S. (2010). Effect of nutrient management practice on the performance of upland rice in a newly developed terraced land. Indian Agriculture 54: (1/2): 13-21.

Evaluation of mulching, intercropping with Sesbania and herbicide use for weed management in dry-seeded rice (Oryza sativa L.). Crop Protection 26: 518524.

Hussain, S., Ramzan, M., Akhter, M. and Aslam, M. 2008. Weed management in direct seeded rice. J. Anim. Pl. Sci., 18: 2-3.

IRRI (International Rice Research Institute) (2003). Main weeds of rice in Asia. [http://www.knowledgebank.irri.org. Accessed on 5 July 2011]

Krishna, A. Biradarpatil, N.K. and Channappayoundar, B.B. (2008). Influence of System of Rice Intensification (SRI) cultivation on seed yield and quality. Karnataka J. Agril. Sci. 21 (3): 369-372.

Latha, M., P. Ratna Prasad, P.R.K. Prasad, R. Lakshmipathy and Srinivasarao, V. 2019. Effect of Integrated Nitrogen Management on Rice and Rice Fallow Rabi Crops. Int. J. Curr. Microbiol. App. Sci. 8(01): 271-280. doi: https://doi.org/10.20546/ijcmas.2019.80 1.030

Mallikarjun, M. and Maity, S.K., 2017. Energetic Evaluation of Integrated Nutrient Management for Nitrogen in Kharif Rice and its Residual Effect on Yellow Sarson. Research Journal of Agricultural Sciences, 8(6), pp.13621365. 
Murthy, R.K. (2012). Productivity and economics of rainfed rice as influenced by integrated nutrient management. Madras Agricultural Journal 99(4/6): 266-270.

Panse VG, Sukhatme PV. 1995. Statistical Methods for Agricultural Workers. New Delhi: Indian Council of Agricultural Research

Parameswari, Y.S. and Srinivas, A. 2014. Influence of weed management practices on nutrient uptake and productivity of rice under different methods of crop establishment. Journal of Rice Research 7 (1 \& 2): 77-86.

Rawat, A., Chaudhary, C.S., Upadhyaya, V.V. and Jain, V. 2012. Efficacy of Bispyribac-Sodium on weed flora and yield of drilled rice. Indian J. Weed Sci., 44(3): 183-185.

Response of Different Weed Management Practices on Yield, Quality and Nutrient Uptake of Kharif Drilled Rice (Oryza sativa L.). Int.J.Curr.Microbiol.App.Sci. 6(4): 1274-1279. doi: https://doi.org/10.20546/ijcmas.2017.60 4.155

Shanmugam, M and Veeraputhran, R. 2001. Effect of organic manure, biofertilizers, inorganic nitrogen and $\mathrm{Zn}$ on growth and yield of Rabi rice. Madras Agricultural Journal. 87(1/3):90-93.

Shendage, G.B., V.M. Kanade, Bheru Lal Kumhar, P.P. Sarawale and Raut, S.D. 2017. Response of Different Weed
Management Practices on Yield, Quality and Nutrient Uptake of Kharif Drilled Rice (Oryza sativa L.). Int.J.Curr.Microbiol.App.Sci., $\quad$ 6(4): 1274-1279.

Singh, N.P., Singh, M. K., Tyagi, S. and Singh, S.S. 2018. Effect of Integrated Nutrient Management on Growth and Yield of Rice (Oryza sativa L.). Int.J.Curr.Microbiol.App.Sci. Special Issue-7: 3671-368.

Subramanyam D., Raghava Reddy C. and Srinivasulu Reddy. 2007. Influence of puddling intensity and water management practices on weed dynamics and yield of transplanted rice (Oryza sativa L). Indian Journal of Agronomy 52 (3): 225-330.

Sudhanshu, S. K. 2013. Effect of in-situ soil moisture conservation practices and different nitrogen sources on rainfed sorghum (Sorghum biocolor L. Moensh) and soil properties. Ph.D. Thesis Andhra Pradesh, Acharya N. G. Ranga Agricultural University, Hyderabad, Rajendranagar.

Vimal Raj Yadav, V. Pratap Singh and Priyanka Kabdal. 2018. Integrated Weed Management in Transplanted Rice - An Effective Approach. Int.J.Curr.Microbiol.App.Sci. $\quad 7(04)$ : 1670- 1679.

Watson, D.J. 1958. The Dependence of Net Assimilation Rate on Leaf Area Index. Annals of Botany, 22, 37-54.

\section{How to cite this article:}

Priyanka Irungbam, L. Nabachandra Singh, Edwin Luikham, N. Okendro Singh, Heisnam Punabati and Bebila Chanu, Y. 2019. Effect of Different Weed and Nutrient Management Practices on the Growth and Yield of Kharif Rice in Manipur Valley. Int.J.Curr.Microbiol.App.Sci. 8(04): 128-137. doi: https://doi.org/10.20546/ijcmas.2019.804.014 